\title{
STUDENTS' PERCEPTION TOWARDS THE USE OF MULTIMEDIA BASED TEACHING MATERIAL
}

\author{
Leora Grahadila Andovita $^{\left.a^{*}\right)}$, Asih Wahyuni ${ }^{a)}$ \\ ${ }^{a)}$ Universitas Pakuan, Bogor, Indonesia \\ ${ }^{*}$ Corresponding Author: leora.andovita@unpak.ac.id
}

Article history: received 28 January 2020; revised 09 February 2020; accepted 16 February 2020

\begin{abstract}
The development of media in a conception of learning technology must have the following characteristics: (a) target oriented; (b) applying the concept of a systems approach; and (c) make use of varied learning resources. Thus the application of media and educational technology, can realize a concept of "teaching less learning more". As technology-based media variations develop, teaching materials become more interesting. Not only text and images, but there is audio, video and animation that make a concept easier to understand. Presentation of information in several ways and forms is often called multimedia. This research method is a survey research that aims to obtain information on students' perceptions of the use of PowToon multimedia-based teaching materials. The questionnaire was used as an instrument to obtain this information. The results of the questionnaire were then analyzed using the Technology Acceptance Model (TAM) model approach; namely: perceived usefulness (perceived usefulness), perceived ease of use, attitude toward using technology, and behavioral intention to use.
\end{abstract}

Keywords: perception; teaching; multimedia.

\section{INTRODUCTION}

Learning should lead to the development of students' creative thinking and increased ability to construct new knowledge to improve good mastery of the subject matter. In learning, lecturers must know the nature of subject matter as material that can develop students 'thinking abilities and understand various forms of teaching materials, media and learning models that can provide a stimulus to students ability to learn.

Along with the rapid development of science and technology, the world of education also felt its impact, namely with the increasingly high level of utilization of computers and the internet. This is influenced by the challenges of the industrial revolution 4.0 which is the digital age. The ability to obtain and understand information through digital media is one of the skills that must be possessed in order to adapt to this era. There are various learning goals that are difficult to achieve just by relying on the teacher's explanation. Therefore, for learning to achieve maximum results, it is necessary to utilize multimedia-based teaching materials.

Multimedia learning is one alternative that can be used to improve student learning achievement. Some of the advantages of multimedia include the involvement of organs such as the ear (audio), eye (visual), and motion (kinesthetic). The involvement of various organs of the body makes information easier to understand (Arsyad [1]). De Porter and Hernacki [2] reveal that humans can absorb a material as much as $50 \%$ of what is heard and seen (audio visual), while from what they see $30 \%$, from what they hear $20 \%$, and from what they read $10 \%$.

The ability of multimedia to enhance interactive processes has been tested because multimedia also has interactive elements as a two-way relationship between teachers and students. Furthermore Jacobs in Munir argued that the relationship between the two paths would create a situation of dialogue between two or more students (Munir, [3]. This dialogue relationship will be easily fostered through the use of teaching materials that have multimedia capacity that will be able to make the learning process interactive. The effectiveness of multimedia will answer students' problems quickly while monitoring their cognitive, affective and psychomotor development.

The use of multimedia-based teaching materials is a form of sustainable development in the field of education which is not only created but also developed forever because the knowledge and information received by students must be up to date. The advantages of teaching materials cannot be denied because they are in accordance with the development of the era. One of the multimedia-based teaching materials is PowToon. PowToon is a video exposure that has built-in cartoon characters, animation models and other cartoon objects that make this video suitable for use as teaching material. Learning like this will create a pleasant learning atmosphere and practice critical thinking skills. This can happen because students will not depend on the presentation of verbal information. Students will practice understanding the multimodal concept presented through verbal text and visual text in the form of moving images in the PowToon video.

Based on this fact, the use of PowToon videos gives rise to various perceptions that are worthy of research as a first step in knowing their usefulness for learning. These various perceptions that arise can occur as a process of students' perspective to understand teaching material presented through PowToon videos. 
The use of varied teaching materials in accordance with the development of the era became one of the latest learning characteristics. By utilizing it, students will be able to bring up their potential abilities. Various perceptions will be formed along with its use in learning. Referring to this background, one main problem can be formulated, namely what are students' perceptions of the use of PowToon multimedia based teaching materials?

Perception is essentially a cognitive process experienced by everyone in understanding information about their environment, both through vision, hearing, appreciation, feeling, and smell (Thoha [4]). Everything that is obtained in the environment, whether seen, heard, lived, felt, and smelled will be processed as information to act.

A simpler opinion was expressed by Sugihartono, et al [5] that perception is the process of translating or interpreting stimuli that enter the sensory organs. Meanwhile, according to Wade and Travis [6], perception is a set of mental actions that regulate sensory impulses into a meaningful pattern.

Robbins and Judge [7] state perception (perception) is a process in which individuals organize and interpret their impressions to give meaning to their environment. A broader view is expressed by Luthans [8] that the key to understanding perception is recognizing that perception is a unique interpretation of a situation, not a recording of the situation. In short, perception is a complex cognitive process that produces a unique picture of the world, which may be somewhat different from reality.

The definition of perception from various experts above can be concluded that perception is the process of translating all information obtained from the environment, both through sight, hearing, appreciation, and feeling. Some experts also argue that perception is a cognitive process.

Teaching materials are a set of learning tools or tools that contain learning materials, methods, boundaries, and ways to evaluate systematically and attractively designed in order to achieve the expected goals, namely achieving competence or subcompetence with all its complexity (Widodo and Jasmadi [9]). This understanding explains that a teaching material must be designed and written with instructional rules because it will be used by teachers to assist and support the learning process.

Pannen [10] revealed that teaching materials are materials or subject matter that are arranged systematically, which are used by teachers or students in the learning process. Meanwhile, Prastowo [11] revealed that teaching materials are all materials (both information, tools, and texts) that are arranged systematically, which presents a complete figure of competencies that will be mastered by students and used in the learning process with the aim of planning and study of learning implementation.

Based on some of these definitions, it can be concluded that teaching materials are all forms of materials used to help teachers and students in order to achieve learning objectives. Teaching material is crucial in the success of a learning. Teaching materials must be mastered and understood by students because they help in the achievement of learning objectives.

Definition of Multimedia is still related to the meaning of a media word, so the meaning and meaning of the term multimedia depart from the media. Within its limits, the word multimedia that is put together can be understood differently from separated multimedia. Multimedia is actually a generic term for a medium that combines various kinds of media both for learning purposes and not. This diversity of media includes text, audio, animation, video, and even simulation. Vaughan [12] provides multimedia definitions as a combination of text, graphics, sound, animation and video. When users get the freedom to control this is called interactive multimedia. Then when learning media is presented in the form of audio which is packaged analogously with cassette tapes, both as supplementary books for the subject matter, then the media are known to us as audio media. This audio media is separate from textbooks, so there are two media, one with text and another audio media. This is where the term is often paired with multimedia, which is the use of more than one media in the learning process. Multimedia is also an effective and efficient teaching and learning medium based on its ability to touch various senses, such as vision, hearing and touch. Like other educational media, multimedia still functions as a tool, method and approach used to establish communication between teachers and students during the teaching and learning process. Munir [3] argues that students can learn the knowledge that is packaged in a multimedia program according to their interests, preferences, talents, needs, knowledge and emotions.

The concept of multimedia is defined by Haffost in Munir as a computer system consisting of hardware and software that makes it easy to combine images, videos, photography, graphics and animation with sound, text and data that are controlled with computer programs. In line with this, Thompson still in Munir defines multimedia as a system that combines images, videos, animations, sounds interactively. Multimedia is the basis of modern technology which includes sound, text, video, images and data. Furht from Atlantic University, Florida, still in Munir, defines multimedia as a combination of various media; text, graphics, animation, images and videos.

The use of instructional media can arouse students' interest and motivation to learn so that students want to study harder and be able to quickly achieve learning goals. What's more some learning media that are designed interactively and attractively are able to make learning actively involved in learning, students' creativity is also increasing with the skill to use a variety of learning media that is varied.

PowToon can bring presentations to life because teaching material is presented through animated videos through dynamic characters and eye-popping images. The use of Powtoon in learning can indeed be said to be a new application and not many people know about it. This application is not much different from PowerPoint to present a teaching material, but Powtoon is more interesting because 
there are many animation choices so that Powtoon can make the classroom atmosphere enjoyable and make the learning process effective. The benefits of using instructional media in the learning process are that it can arouse new desires and interests, arouse motivation and stimulation of learning activities, and even bring psychological influences on students.

\section{RESEARCH METHODS}

The method used in this research is survey research. This research is a research that does not give any treatment to respondents, only collects data using standardized instruments. The data collection technique is carried out by distributing written questionnaires or conducting interviews on a number of subjects, without any conditioning on the subject. This research is included in the survey research because it has several characteristics, such as producing descriptions of various aspects of the population under study and having questions raised so that the answers can be used as data for analysis. The survey method was used because what was studied was the students' perception of the use of PowToon multimedia-based teaching materials.

Data collection tool in this study used a questionnaire / questionnaire that was distributed to students. The sampling technique used in this study was purposive sampling. The sample chosen for this study was the second semester students of Class A English Language Education Study Program, Faculty of Teacher Training and Educational Sciences, Universitas Pakuan, as many as 24 students. This class was chosen as a sample because it became a pilot project using PowToon teaching materials. The steps in this research are (1) the preparation of questionnaire instruments based on the TAM model that will be used for data collection; (2) collecting data with a questionnaire; (3) the data obtained are then analyzed descriptively.

In this study an analysis technique will be conducted using the Technology Acceptance Model (TAM) to determine students' perceptions of the use of multimediabased teaching materials PowToon. The technology acceptance model (TAM) is an information technology system acceptance model that will be used by users. The technology acceptance model or Technology Acceptance Model (TAM) was developed based on the TRA (Theory of Reasoned Action) model. This model shows that the use of technology will help improve one's work efficiency so that it will support its effectiveness.

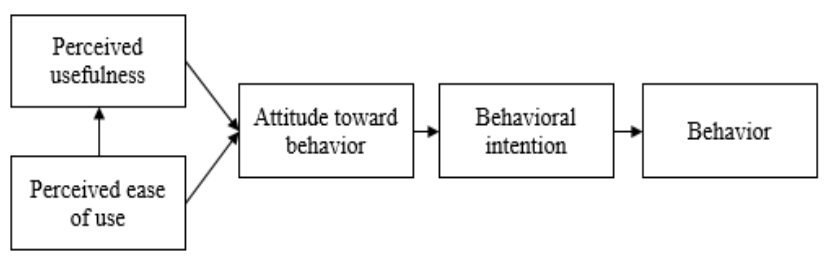

Figure 1. Technology Acceptance Model (TAM)
In the TAM model, there are five constructs namely perceived ease use ease, perceived usefulness, attitude toward using, behavioral intention and actual technology use. This study uses a research instrument in the form of a questionnaire. The questionnaire was prepared based on four of the five TAM components. The following table 1 is the components and indicators used in this study.

Tabel 1. Students' Perception Questionnaire

\begin{tabular}{|c|l|l|}
\hline No. & \multicolumn{1}{|c|}{ Components } & \multicolumn{1}{c|}{ Indicators } \\
\hline 1. & $\begin{array}{l}\text { Perception of perceived } \\
\text { usefulness }\end{array}$ & $\begin{array}{l}\text { Benefits of teaching } \\
\text { materials used }\end{array}$ \\
\hline 2. & Perception of perceive ease of use & $\begin{array}{l}\text { Students' believe in the } \\
\text { ability to use } \\
\text { multimedia as teaching } \\
\text { material }\end{array}$ \\
\hline 3. & $\begin{array}{l}\text { Perception of attitude toward } \\
\text { using technology }\end{array}$ & $\begin{array}{l}\text { Predicting the behavior } \\
\text { of students' intentions } \\
\text { to use teaching } \\
\text { materials }\end{array}$ \\
\hline 4. & $\begin{array}{l}\text { Perception of behavioral intention } \\
\text { to use }\end{array}$ & $\begin{array}{l}\text { Students want to } \\
\text { continue to use } \\
\text { multimedia-based } \\
\text { teaching materials }\end{array}$ \\
\hline
\end{tabular}

\section{RESULTS AND DISCUSSION}

\section{Perceived Usefulness}

Perceived usefulness is defined to the extent that someone believes that using a technology will improve the performance of his work. This construct is influenced by the construct of ease of use. Usability is a significant and important construct that influences attitudes, intentions and behavior. In this study, students felt the benefits of using PowToon. By using PowToon, subject matter can be more easily understood because the material is presented in a dense and interesting manner. The benefits felt by students are lessons can be understood more quickly, improve performance, increase productivity and increase learning effectiveness.

2. Perceive Ease of Use

Perceive ease of use is a feeling of the user, namely students who consider PowToon to be an easy-to-use technology so that it does not require much effort to understand and use it. This research shows that students can use PowToon media easily. It can be interpreted that students who use PowToon can feel the ease when using it and are easily accessible so that it can ease in completing daily tasks. Thus the use of PowToon can improve their performance.

\section{Attitudes Toward Using Technology}

Attitude toward using technology or attitude can be defined as positive or negative feelings from someone if they have to do the behavior that will be determined. Attitude affects intention and is influenced by ease of use and usability. In this study, it can be seen that students have an interest or desire to keep using PowToon. In other words, students accept PowToon as a medium that can support their learning. 
4. Behavioral Intention to Use

Behavioral intention to use is an intention or motivation in users to use PowToon in learning activities. In this case, students as PowToon users show a positive attitude towards the technology used. Students use PowToon to help them completing their assignments and they will continue to use them at a later time.

\section{CONCLUSION}

In this study, four constructs in the Technology Acceptance Model (TAM) approach were used to determine students' perceptions of PowToon as a learning medium. The four constructs are perceived usefulness, perceived ease of use, attitude toward using technology, and behavioral intention to use technology. The results showed a positive student perception of the use of PowToon as a learning medium.

This shows that PowToon users feel this media is easy to use so that it will provide benefits for students. Students will tend to have the intention to continue to use PowToon because it can meet their needs efficiently. Positive student behavior toward using PowToon can influence their intention to keep using PowToon regularly.

\section{REFERENCES}

[1] Arsyad, Azhar. 2006. Media Pembelajaran. Jakarta: Rajagrafindo Persada.

[2] DePorter, Bobbi dan Hernacki, Mike. 2000. Quantum Learning: Membiasakan Belajar Nyaman dan Menyenangkan. Bandung: Kaifa.

[3] Munir. 2000. Kurikulum Berbasis Teknologi Informasi dan Komunikasi. Bandung: Alfabeta.

[4] Thoha, Miftah. 2010. Kepemimpinan dalam Manajemen. Jakarta: PT. Grafindo Jakarta.

[5] Sugihartono. 2007. Psikologi Pendidikan. Yogyakarta: UNY Press.

[6] Wade, Carole dan Travis, Carol. 2007. Psikologi Jilid I (edisi 9). Jakarta: Erlangga.

[7] Robbins, Stephen P. dan Judge, Timothy A. 2009. Perilaku Organisasi Buku I. Jakarta: Salemba Empat.

[8] Luthans, Fred. 1992. Organizational Behavior. New York: McGraw Hill Company.

[9] Widodo, Chomsin S. dan Jasmadi. 2008. Panduan Menyusun Bahan Ajar Berbasis Kompetensi. Jakarta: PT. Elex Media Komputindo.

[10] Pannen, Paulina dan Purwanto. 2001. Penulisan Bahan Ajar. Jakarta: Dirjen Dikti Depdiknas.

[11] Prastowo, Andi. 2001. Panduan Kreatif Membuat Bahan Ajar Inovatif. Yogyakarta: Diva Press.

[12] Vaughan, Tay. 2004. Multimedia: Making It Work. Yogyakarta: Tim Penerbit Andi. 